University of Rhode Island

DigitalCommons@URI

\title{
Implications of climate change for shipping: Ports and supply chains
}

\author{
Austin Becker \\ University of Rhode Island, abecker@uri.edu \\ Adolf K. Y. Ng \\ Darryn McEvoy \\ Jane Mullett
}

Follow this and additional works at: https://digitalcommons.uri.edu/maf_facpubs

The University of Rhode Island Faculty have made this article openly available.

Please let us know how Open Access to this research benefits you.

This is a pre-publication author manuscript of the final, published article.

Terms of Use

This article is made available under the terms and conditions applicable towards Open Access Policy Articles, as set forth in our Terms of Use.

\section{Citation/Publisher Attribution}

Becker, A., Ng,A., McEvoy, D., Mullett, J., (2018). "Implications of climate change for shipping: Ports and supply chains." Wiley Interdisciplinary Reviews: Climate Change: e508. doi: 10.1002/wcc.508.

Available at: https://doi.org/10.1002/wcc.508

This Article is brought to you for free and open access by the Marine Affairs at DigitalCommons@URI. It has been accepted for inclusion in Marine Affairs Faculty Publications by an authorized administrator of DigitalCommons@URI. For more information, please contact digitalcommons-group@uri.edu. 


\title{
IMPLICATIONS OF CLIMATE CHANGE FOR SHIPPING: PORTS AND SUPPLY CHAINS
}

\author{
Austin BECKER ${ }^{\dagger} \diamond$, Adolf K.Y. NG $\diamond \triangle$, Darryn McEVOY*, Jane MULLETT*
}

\author{
-Department of Marine Affairs, University of Rhode Island, RI, USA

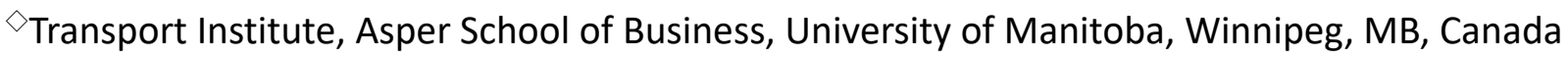 \\ $\triangle$ Department of Supply Chain Management, Asper School of Business, University of Manitoba, \\ Winnipeg, MB, Canada \\ * School of Engineering, RMIT University, Australia \\ Wiley Interdisciplinary Reviews: Climate Change
}

\section{Cite as:}

Becker, A., Ng,A., McEvoy, D., Mullett, J., (2018). "Implications of climate change for shipping: Ports and supply chains." Wiley Interdisciplinary Reviews: Climate Change: e508. doi:

10.1002/wcc.508.

\begin{abstract}
Ports are an important economic actor - at local, national and international scales - that have been identified as being vulnerable to future changes to the climate. This paper details the findings from an international review of state-of-theart knowledge concerning climate risks, and adaptation responses, for ports and their supply chains. Evidence from both academic and grey literature indicates that there has already been major damage and disruption to ports across the world from climate-related hazards and that such impacts are projected to increase in the years and decades to come. Findings indicate that while a substantial - and growing - body of scientific evidence on coastal risks and potential adaptation options is acting as a stimulus for port authorities to explicitly consider the risks for their assets and operations, only a notable few have actually made the next step towards implementing adaptation strategies. This paper concludes by putting forward constructive recommendations for the sector and suggestions for research to address remaining knowledge gaps. It emphasizes a call for collaboration between the research and practice communities, as well as the need to engage a broad range of stakeholders in the adaptation planning process.
\end{abstract}

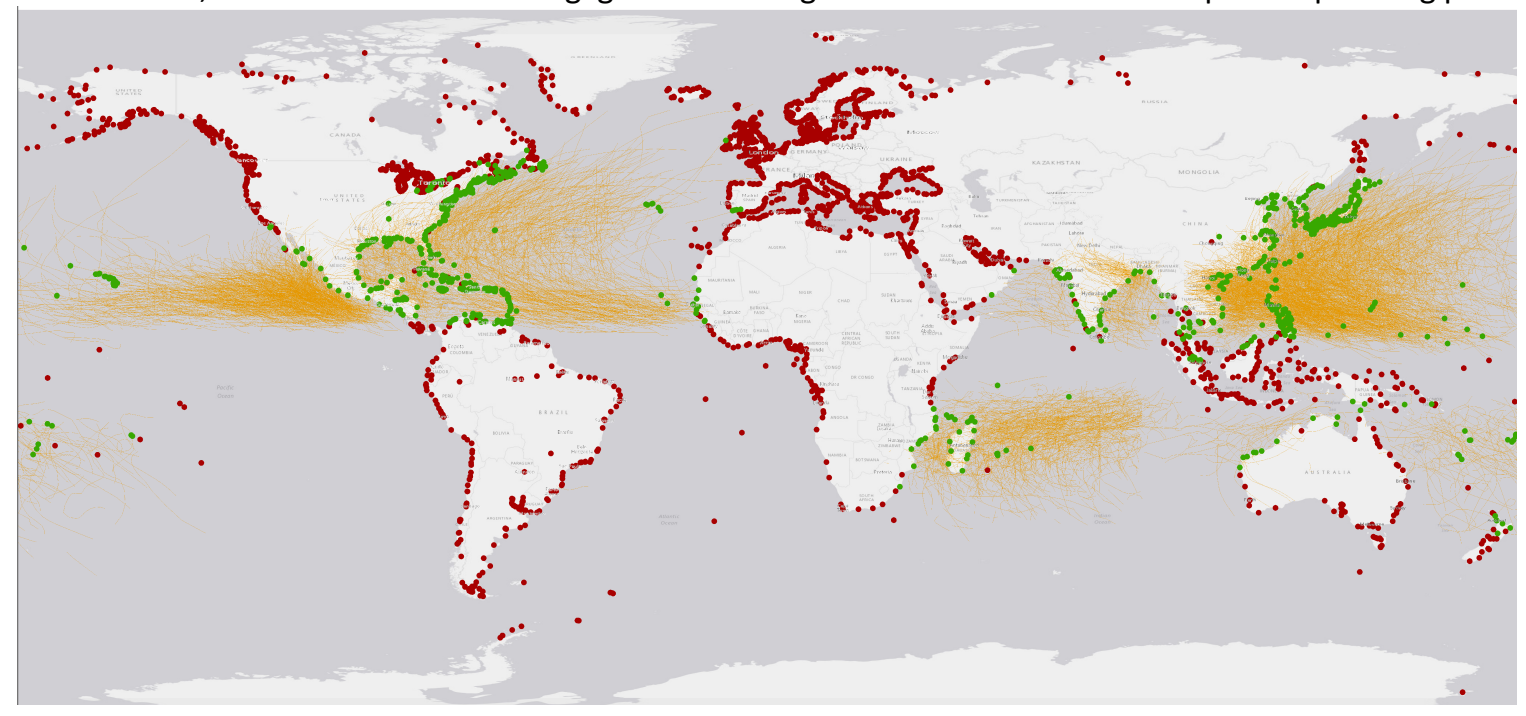

Graphical Abstract - Map showing 1100 ports (green) out of 3700 total (red) that have come within $50 \mathrm{~km}$ of a tropical storm from 1960 - 2016. Storm tracks in orange. (data from World Port Index and https://www.ncdc.noaa.gov/ibtracs/). Increase in intensity of tropical storms is one of many climate drivers expected to affect seaports and supply chains. 


\section{1 - Introduction}

Over 3,700 maritime ports ${ }^{1}$ and their supply chains enable global and local commerce, fulfilling a wide variety of functions for the local, regional, and global economy ${ }^{2-4}$. They provide jobs, facilitate trade, and serve as links between the hinterlands (back region) and the forelands (seaward region) of their markets. Port infrastructure requires deep water, quality connections for rail and road, and some protection from atmospheric and ocean hazards. Most coastal cities originally grew around a port hub and global trade routes then evolved into a network that now connects port cities across the world. This 'inter-connectedness' means that even a short-term loss of port capacity (e.g., due to a natural disaster) can cause local and global ripple effects in logistics and trade-dependent industries ${ }^{5-7}$, such as imported food, energy, and assembled products.

Many ports regularly experience natural hazard events and about a third of the world's ports are located in areas prone to tropical storms (Figure 1$)^{8}$. Climate change will likely amplify the impacts of future coastal hazards. Projected changes include an increase in the frequency and intensity of 'extreme' atmospheric events - shocks such as storms, heavy precipitation, and heat waves ${ }^{9}$; as well as longer-term changes to climatic variables resulting in 'slow onset' changes like sea level rise, wave climatology, and sea-surface salinity (leading to higher rates of corrosion) ${ }^{10}$. However, at present, these longer-term stresses (rather than shocks) are generally not being factored into port management. Furthermore, climate change impacts will not be uniform globally and therefore decision makers will need localized (downscaled) climate scenarios to inform the range of possible climate 'futures' for consideration by individual ports and their supply chains.

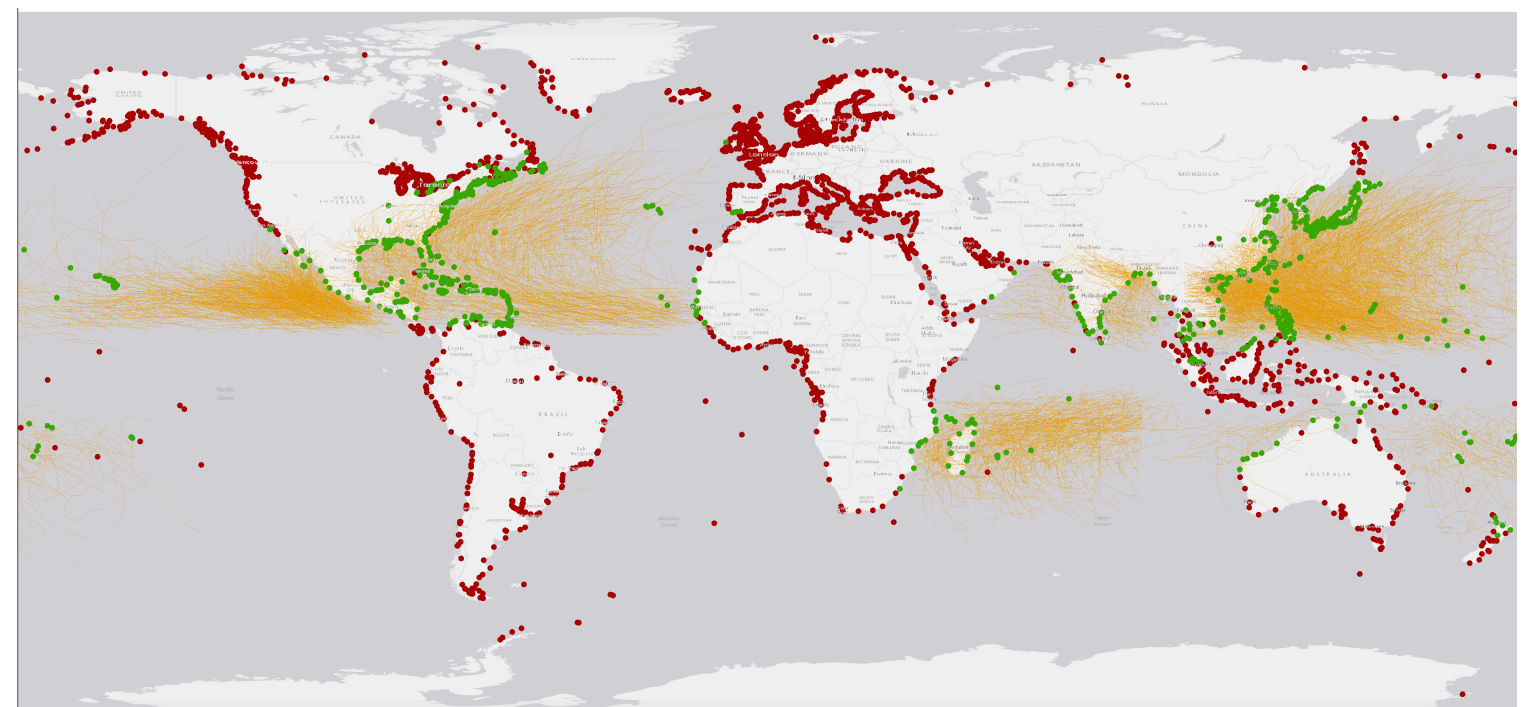

Figure 1 - Map showing 1100 ports (green) out of 3700 total (red) that have come within 50km of a tropical storm from 1960 2016. Storm tracks in orange. (data from World Port Index and https://www.ncdc.noaa.gov/ibtracs/)

In response, this paper provides a comprehensive review of the current state of the literature regarding climate impacts, and projected future climate risks, affecting ports and their supply chains; as well as providing case study examples of climate assessments and sectoral adaptation efforts to 
date. In addition to providing an overview of current knowledge and practice, this paper identifies remaining research gaps and offers insights and recommendations on the 'next steps' that ports and supply chains could implement to enhance their resilience to a changing climate.

The paper first discusses the role of ports in local, regional and global economies, and provides a summary of climate risks posed to these systems as currently understood by the scientific community. It then reflects on the latest conceptual thinking that is informing climate resilience actions and adaptation planning, before highlighting documented evidence of practical actions that port authorities are carrying gout across the world to enhance the resilience of port infrastructure, operations, and supply chain logistics over the coming century. The paper concludes by highlighting continuing gaps in knowledge and recommending pathways for progressing climate resilient planning for ports.

\section{2 - Ports as links in supply chains in local, regional, and global economies}

The development of shipping, especially container liner shipping, has fundamentally transformed port operation, planning, and management since the $1960 \mathrm{~s}^{11}$. First, the increase in ship sizes and the restructuring of shipping networks reduced the number of port calls due to tighter physical (e.g., deeper water draught) and economic (e.g., utility rates of ships) constraints. This intensified interport competition, especially for the largest ports serving the major markets ${ }^{12}$. Second, as mentioned, ports are nodal components along transportation, logistics, and supply chains. Different components along these systems; such as ship, cranes, warehouses, rail and road links; must function together as cargoes move from producers to consumers at the right place and at the right time ${ }^{12}$.

In this case, port infrastructures and facilities serve as the convergence points between different transportation and logistics components/stakeholders; hence they are pivotal in defining the smooth operation of global supply chains. In other words, ports never operate in isolation, but as parts of complex transportation, logistics, and supply chain systems ${ }^{12}$. Thus, any climate-related disruptions to ports have broader implications for the resilience of the global economy and human welfare. The impacts of shutdown of Port of New York/New Jersey (USA) due to Hurricane Sandy in 2012 discussed in Section 3 below, serve as clear examples of how shocks can impact whole port systems. Moreover, being the interaction points between land and water where people and cargoes interact, ports are the economic drivers of, and linked to, the cultural centers of cities and surrounding regions, and thus have an influence on the wellbeing of these cities and regions. For example, many ports provide not only cargo-handling services, but also different 'value-added' services (e.g., quality control, re-packaging, assembly, calibration), with the efficiency of the logistical entities dependent on ports as the integrating catalyst ${ }^{13,14}$. All these contribute to a significant narrowing of 'margins of error' for ports for operational disruption or total shutdowns ${ }^{15}$. Any negative impacts posed by future climate change would add more pressure to such margins.

To summarize, as key nodes that link countries and regions together through trade, the risks to ports posed by climate change have broad implications for both local and global economies. As such, the uptake of resilience measures by decision-makers will need high-quality theoretical analysis, highly 
innovative assessment methodologies, and insightful empirical global experiences to identify appropriate practices, planning, and policies to effectively manage the impacts posed by climate change on transportation, logistics, and supply chains.

\section{3 - Climate-related impacts and future risks for ports and supply chains}

Port infrastructure, operations, and supply chains, are vulnerable to future changes to water, oceanic, and atmospheric conditions (Box 1). Oceanic and water impacts include changes to: mean relative sea level, storm water levels, wind waves and swell, tidal regime, sedimentation rates, waterborne immigration of species, water temperature, ice levels, salinity and acidity ${ }^{16}$. Atmospheric impacts include changes to average temperature, heatwaves and droughts, as well as precipitation, wind speed and direction, associated with storms including hurricanes/typhoons. With some exceptions, the IPCC ${ }^{9}$ reports observed increases in extreme hazards (Box 1), such as heavy precipitation events, droughts and heatwaves.

Vulnerability is defined by the IPCC as "the propensity or predisposition to be adversely affected. Vulnerability encompasses a variety of concepts and elements including sensitivity or susceptibility to harm and lack of capacity to cope and adapt."(p. 1775) ${ }^{49}$

Extreme hazards are generally defined in terms of the Annual Exceedance Probability (AEP) or the Average Recurrence Interval (ARI) (i.e., how often an event may occur or its return period in years). For example, The Rotterdam Maeslant barrier is built to withstand up to a one-in-10,000-year storm. However, one of the defining features of climate change is that the ARI is not static, i.e., under some future climate scenarios a one-in-100 year storm becomes a one-in-three year storm ${ }^{18}$.

Box 1 - Definitions

While there is no evidence of an increase in overall tropical cyclone activity, trends show that there has been an increase in the number of intense storms ${ }^{10}$ with some models projecting more intense hurricanes for the Atlantic Basin ${ }^{17}$. Higher storm surges and river floods ${ }^{18-20}$, increased tropical storm

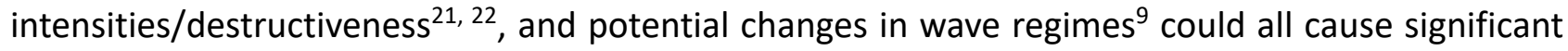
damage and operational delays at ports ${ }^{23-26}$.

As well as the impacts of extreme events, slow onset changes such as sea level rise are yet to fully impact ports, though will increasingly do so in the future. Scientists expect global sea level rise ranges from 0.6 to 2.0 meters by $2100^{27-29}$ and some project an upper bound of 4.3 meters of rise by $2200^{30}$. Sea level rise can have major impacts when reinforced by increased storm surge heights and associated flooding, and recent modeling indicates that the accepted understanding of frequency and extent of storm surge and flooding may be conservative and have to be revised upwards $\mathrm{s}^{31-33}$.

Significant economic costs result from extreme events, involving direct damages to infrastructure and superstructure of ports and their supply chains, indirect costs to employment sectors and the taxpayer, as well as intangible consequences such as pollution in an estuary or a lowering in quality 
of life for port neighbors ${ }^{34}$. However, much of the available information on impacts to port logistics is anecdotal and preliminary, and constitutes a significant remaining knowledge gap.

Many ports have been hit directly by tropical storms, with recorded damages totaling in the billions of dollars ${ }^{35}$. In the U.S. for example, Hurricane Katrina caused $\$ 100$ million in damages to the State of Mississippi's ports alone ${ }^{36}$, and Superstorm Sandy shut down the Port of New York/New Jersey for over eight days ${ }^{26}$. In 2015, Cyclone Pam severely damaged Port Vila port, Vanuatu ${ }^{37}$, which is the main port for the Pacific Island Nation and the city's seafront is still being reconstructed (as of 2017). Elsewhere, Typhoon Maemi left the Port of Bhusan (South Korea) inoperable for 91 days in $2013^{38}$.

Ports and hinterlands are closely linked and disruptions along any supply chain components may impact the whole chain ${ }^{14,39}$. An excellent example is the damage of railroads connecting the port of Churchill (Manitoba, Canada) with southern Canada, where the washouts of certain parts of the railroads by serious floods in May 2017 have contributed to the nearly 100\% suspension of the supply of food and other necessities to Churchill and nearby communities through non-aviation means ${ }^{40}$.

Other climate-related extreme events have also caused significant disruptions to port operations and their associated supply chains. The port for Chennai, India, was severely damaged by floods in 2015, impacting the road and rail system with knock-on implications for the entire supply chain; including, "importers, exporters, carriers, forwarders, warehouses and container freight stations" ${ }^{41}$. Similarly, the 2011 flooding of inland coal mines in Queensland, Australia, reduced the throughput at Port Gladstone by approximately 40 million tons, and heat waves in southern Australia in 2009 resulted in shutdowns of sections of the Port of Melbourne for three days ${ }^{42,43}$. In the UK, the winter floods of 2013-2014 caused an estimated $£ 1.8$ million in damage to ports ${ }^{44}$. In South America, extreme rainfall resulting in flooding and landslides forced the closure of the Paranaguá Port in 2008, one of the most important ports in Brazil, resulting in losses of \$US 350 million $^{45}$.

Some models have shown that, while all supply chains will have diminished resilience as climate disruptions increase, a more complex supply chain, with a higher number of nodes and links, will tend to be more resilient to climate-related shocks ${ }^{46}$. The impacts of climate change on flows of materials, energy, and other supply chains, however, remains under studied ${ }^{47}$. Traditional approaches to risk management theory tend to not take into account a projected increase in the probability of an event and other complexities associated with climate change ${ }^{48}$. A paucity of data, too, remains a challenge for understanding risk to supply chains, though there are efforts underway to develop new tools to collect, analyze, and make public relevant datasets on a global scale ${ }^{47}$.

The modeling and data that are used to develop future climate projections have been evolving and improving over the past 50 years ${ }^{50}$. However, the process remains complex. The generation of highly technical scenario outputs involves selecting climate models or model ensembles, choosing spatial and temporal resolution, representing different emission scenarios, accounting for natural variability and uncertainties, as well as balancing the needs of scientific credibility with usability ${ }^{51}$. Due to this complexity, port authorities would benefit from closer engagement with the scientific community to better understand the dynamic nature of climate risks to ports 
and their supply chains, and to use this evidence base to build resilience to future environmental conditions. It is also worth noting that improvements in regional model projections, both of future climate and of its impacts, are reliant on good quality observations. However, there is currently a decreasing trend of investment in monitoring networks and onsite monitoring that port authorities should be encouraged to reverse ${ }^{52}$.

\section{4 - Concept: port resilience to climate risks and adaptation planning}

"Resilience" has different meanings for different stakeholders; its modern conception is most commonly linked to ecology ${ }^{53}$ or engineering ${ }^{54}$. Both these communities of practice broadly understand resilience as the ability to resist and/or quickly return to a functioning state after a shock to a defined system. More recently, there has been increased interest in socio-ecological resilience, particularly the ability of humans to learn from experience, accumulate new knowledge, and hence make informed adaptation decisions that increase resilience ${ }^{55}$. In general, a resilient port or supply chain may be understood to be one that can, "withstand an extreme event without suffering devastating losses, damage, diminished productivity or quality of life, without a large amount of assistance from outside the community" 56 .

In the face of climate drivers (e.g., sea level rise, extreme heat, stronger storms), a climate-resilient port may continue to fulfill the following long-term goals: serve as a conduit for the exchange of resources, materials, and finished products; facilitate business success and profit to firms; provide for local, state, and/or national economic growth and stability; and deliver a public good that minimizes environmental harm and contributes to residents' quality of life ${ }^{34}$. Strengthening resilience requires an understanding of the risks and vulnerabilities of greatest concern and a plan of action for implementing resilience-building responses, including an understanding of the extent and the limits of resilience. The following section describes current approaches and barriers to resilience planning for ports

\section{1: Climate risk and vulnerability assessment approaches}

There is no scarcity of research investigating coastal climate risks and adaptation, notably sea level rise $^{57-60}$, vulnerability of coastal areas ${ }^{61-65}$, and the construction of coastal defenses via marine ecosystems ${ }^{66,67}$. Less well studied are the impacts on port outdoor workers; though some anecdotal evidence is available ${ }^{42}$. Some of these studies illustrate the urgency for adaptation plans to safeguard economic activities, while others investigate the relationship between climate change and continued resilience of the built environment. Notable examples include Rosenzweig et al ${ }^{68}$ who analyzed New York City's climate adaptation plan with an emphasis on the protection of coastal infrastructure; and Hanson et al. ${ }^{69}$ who measured the exposure of major ports and port cities to the impacts posed by a changing climate. Preston et $a l^{70}$ evaluated 57 climate adaptation plans around the world focusing on the 'quality' of their planning process, while Osthorst and Manz ${ }^{71}$ investigated the changing relationship between stakeholders and regions when developing adaptation strategies in Germany. Australian studies assessing climate risks to ports include Mullett and McEvoy ${ }^{72}$ and $\mathrm{Ng} \mathrm{et}$ al $^{73}$. Other examples of research in this area include Stenek et $a l^{74}$ and Becker et $a l^{8}$ who studied the impacts and challenges imposed by climate change on ports more broadly. These reports advocate climate assessments and the development of adaptation plans by port authorities. 
Across the globe, scholars, policymakers, and industrial practitioners grapple with the complexities of uncertainties in climate projections, high upfront costs, and often-unquantifiable benefits of resilience investments. As yet, there are no generally applied methods for gathering and assessing these data and a wide variety of approaches are being explored. Indeed, quantifying the potential monetary impacts from a future storm, a set of storms, or the rise in sea level (for example) remains very difficult. Thus, while perhaps less satisfying than a precise calculation of potential damages in monetary terms, accounting for the experience, and perceptions, of experts directly involved with port operations and planning serves as a foundational step toward choosing and implementing the best new practices for any given port.

The process of planned adaptation generally begins with identifying the problem, including understanding impacts, risks, opportunities, and vulnerabilities ${ }^{75}$. This is the subject of a great deal of activity in this emerging research area ${ }^{76,77}$. Though the process is iterative, problem and solution identification generally takes place early on. For some ports, this process has recently begun $42,74,78$, and indeed, ports are evidently adapting to, or coping with, the current incremental increase in climate impacts (including absorbing costs to operations through increased down-time), but in general a clearer definition of the extent of anticipated issues and solutions for ports is still needed ${ }^{79}$, 80.

The first stage of planning for climate change establishes the context and defines the system under investigation (including the boundaries of the system and the different elements at risk). Often, this includes port assets and operations and extends to maritime supply chains. Both the seaward-side of operations (ship movement and mooring, loading and unloading) and the supply chain hinterland (road and rail movement, intermodal hubs) can be impacted by climate variability 42 . The second stage of a climate change assessment is then to define the problem: What are the key climate impacts that a port needs to adapt to? Generic adaptation actions cannot be adopted without appropriate site level investigation as climate change impacts are specific to each port; even longterm global changes such as sea level rise will not affect all ports similarly For this reason, some port authorities have begun to undertake location-specific climate change assessments using a variety of methodologies ${ }^{81,82}$.

One such approach is to undertake a climate risk assessment, which is often based on the international standard ISO 31000:2009, Risk management - Principles and guidelines. This provides the principles, framework and process for managing risk. This can be attractive to port businesses that already use risk management tools to deal with other uncertainties of the business, such as trade fluctuations. In Australia, for example, this risk-based approach has been extended to a national standard on Climate change adaptation for settlements and infrastructure (AS5334-2013), which includes the explicit identification and treatment of climate risks. A risk-based approach takes the climate hazard as the starting point of analysis and introduces state-of-the-art climate scenarios to an assessment by experts of the likelihood and consequence of a particular climate-related event (see for example ${ }^{83-85}$ ). This approach tends to emphasize climate 'extremes' rather than longer-term gradual change. As a consequence, uncertainties in the climate data (catered for by confidence 
levels in the assessment but sometimes used as a justification for deferring decisions), and scenarios that look far into the future often misalign with many shorter organizational planning horizons ${ }^{8,16}$.

A vulnerability-led assessment offers an alternative approach (see, for example, the UN-Habitat series of vulnerability assessments for selected cities in the Asia Pacific region ${ }^{86}$ ). Starting from a consideration of the vulnerability of the system and its component parts to current day climaterelated impacts (including recent trends), a vulnerability-led assessment provides a useful initial foundation for considering changing risk profiles over time. One tool created for this purposes walks port decision makers through a checklist to help them understand where their vulnerabilities may be found ${ }^{87}$. A hybrid vulnerability and risk assessment framework has been put forward as one way to combine the merits of the two approaches (Figure 2). Whichever approach leaders take to conduct the assessment, they must be cognizant of any existing risk management strategy that a port authority already has in place.

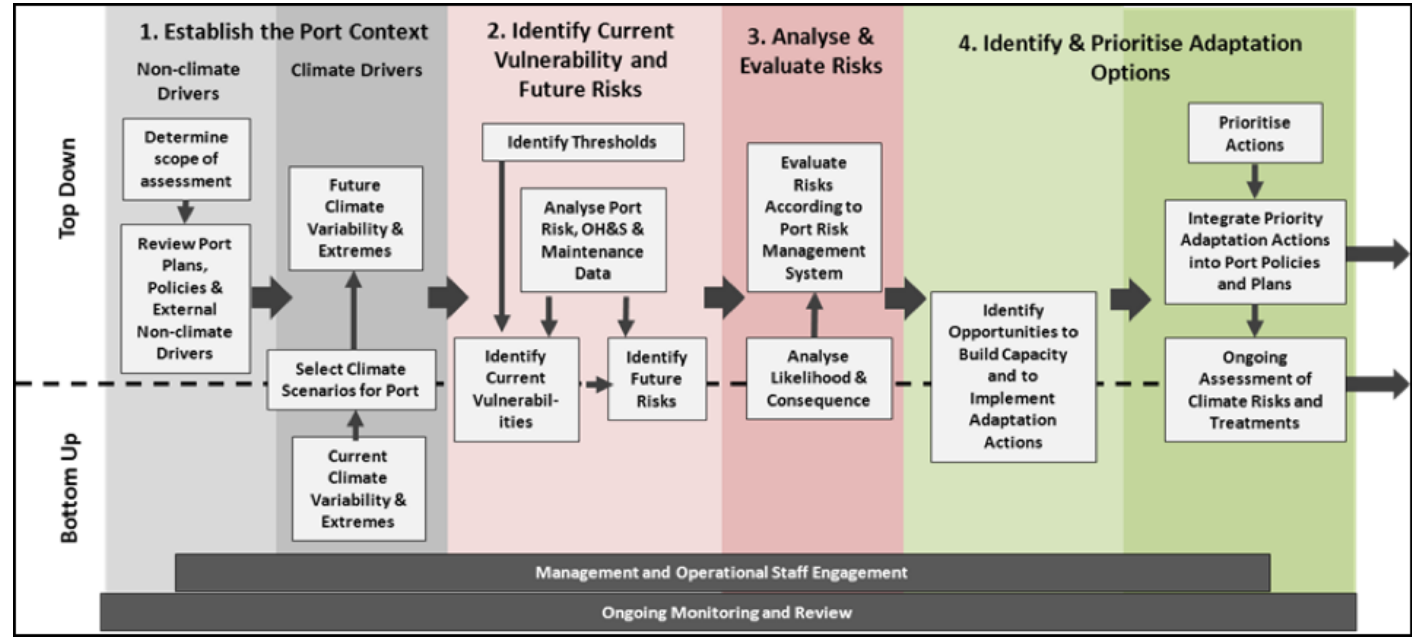

Figure 2 - Hybrid vulnerability/risk assessment process for ports ${ }^{88}$

\subsection{Adaptation planning for ports}

Although many risks associated with climate change are not inherently "new," there are still few standards for addressing climate risks. Modifying this approach to incorporate current day vulnerabilities to extreme weather events, as well as considering future climate impacts to create a "hybrid risk/ vulnerability assessment", as indicated in the previous section, can address two key barriers to effective climate change adaptation at ports: inconsistency in planning horizons, and uncertainty of future localized climate projections (in combination with other non-climate uncertainties).

In terms of planning horizons, researchers have noted $8,16,89$ that the short organizational port planning timeframe of 5-15 years does not easily facilitate consideration of climate impacts that may not materialize for 30 - 90 years. However, port infrastructure generally lasts beyond these short planning timeframes, and maintenance, retro-fitting, and future development of infrastructure, needs to be fit-for-purpose for future climate conditions.

With a firmer sense of the nature of the challenge faced by port stakeholders, the adaptation process can move to identifying potential solutions ${ }^{90-93}$ in a shift from understanding the nature of the 
problem, to selecting and implementing adaptation strategies. Plans for climate adaptation must focus both on short-term solutions (e.g., elevating electrical equipment or developing better emergency response plans) and longer-term solutions (e.g., capital improvements or major changes to operations - see Table 1 for other examples). Once measures are identified, the weighing of costs and benefits, securing necessary funding, design selection, environmental permit application and actual construction (of new structures) or facilitation (of drafting new policies and plans or other 'softer' solutions) can begin. This work can be particularly vexing, as many strategies require significant investments today and a payoff that may not be realized for several more decades.

However, as projected changes in the oceans and atmosphere progress through this century and beyond, many coastal decision makers, particularly those with responsibility for port operations and development, will likely begin to take actions to adapt. In many cases, they will begin with inexpensive changes or reactive measures following a climate-related impact. For example, the 2009 heatwave in SE Victoria melted the tarmac on some port wharves in Melbourne causing loading work to cease. These wharves were subsequently resurfaced in concrete, eliminating the problem for future heat events.

Other inexpensive strategies include elevating utilities, enhancing flood berms, or storing data backups offsite ${ }^{94}$. Soft strategies such as creating new planning documents, changes to budgets, increasing insurance and adopting new design standards can usefully augment hard strategies such as building new coastal defenses or raising port elevations. However, the key to these is incorporating multiple stakeholders into the adaptation process, from engineers, to planners, insurers, regulators and others (Table 1).

Table 1 - Selected climate change impacts, responses and relevant actors ${ }^{79}$

\begin{tabular}{|c|c|c|c|c|c|c|c|c|c|c|}
\hline \multirow{2}{*}{$\begin{array}{l}\text { Potential impacts from climate change: } \\
\text { Increase in height of waves that reach the } \\
\text { port, flooding of port and transport } \\
\text { installations, increase in coastal erosion, } \\
\text { increased downtime due to flooding and } \\
\text { higher winds, Increase sedimentation and } \\
\text { erosion rates, Operational delays }\end{array}$} & \multirow[t]{2}{*}{ Possible responses } & \multicolumn{9}{|c|}{ Stakeholders to be engaged } \\
\hline & & 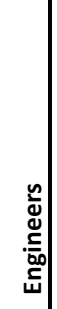 & 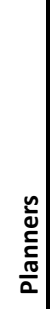 & 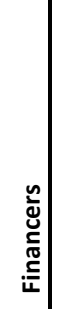 & 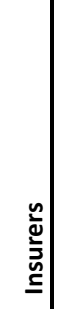 & 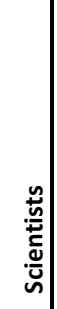 & 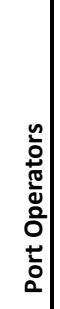 & $\begin{array}{l}\frac{n}{\vdots} \\
\frac{a}{2} \\
\frac{2}{n}\end{array}$ & 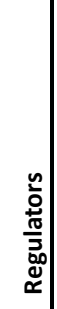 & 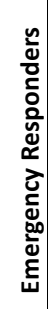 \\
\hline \multirow[t]{8}{*}{ Soft strategies and least regrets } & Enhance emergency evacuation plans & $\checkmark$ & $\checkmark$ & & & & $\checkmark$ & & & $\checkmark$ \\
\hline & Consider adaptation in long-range plans & $\boldsymbol{V}$ & $\checkmark$ & $\boldsymbol{V}$ & $\checkmark$ & & $\checkmark$ & & $\checkmark$ & 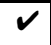 \\
\hline & Learn from those at the forefront & $\boldsymbol{v}$ & $\checkmark$ & $\boldsymbol{v}$ & $\checkmark$ & $\checkmark$ & $\checkmark$ & $\checkmark$ & $\checkmark$ & $\checkmark$ \\
\hline & $\begin{array}{l}\text { Create financial instruments to support } \\
\text { adaptation }\end{array}$ & & & $\checkmark$ & $\checkmark$ & & & & $\checkmark$ & \\
\hline & $\begin{array}{l}\text { Improve decision support tools and } \\
\text { information }\end{array}$ & $\checkmark$ & $\checkmark$ & & & $\checkmark$ & & & & \\
\hline & $\begin{array}{l}\text { Increase standards of port construction to } \\
\text { deal with higher winds }\end{array}$ & $\boldsymbol{v}$ & & & & & & & $\checkmark$ & \\
\hline & $\begin{array}{l}\text { Increase funding for dredging and beach } \\
\text { nourishment programs }\end{array}$ & $\checkmark$ & $\checkmark$ & $\boldsymbol{v}$ & & $\checkmark$ & & & $\checkmark$ & \\
\hline & $\begin{array}{l}\text { Increase standards of port construction to } \\
\text { deal with higher winds }\end{array}$ & $\checkmark$ & & & & & & & $\checkmark$ & \\
\hline Hard strategies & Expand dredging and & $\checkmark$ & $\checkmark$ & $\checkmark$ & & $\checkmark$ & $\checkmark$ & & $\checkmark$ & \\
\hline
\end{tabular}




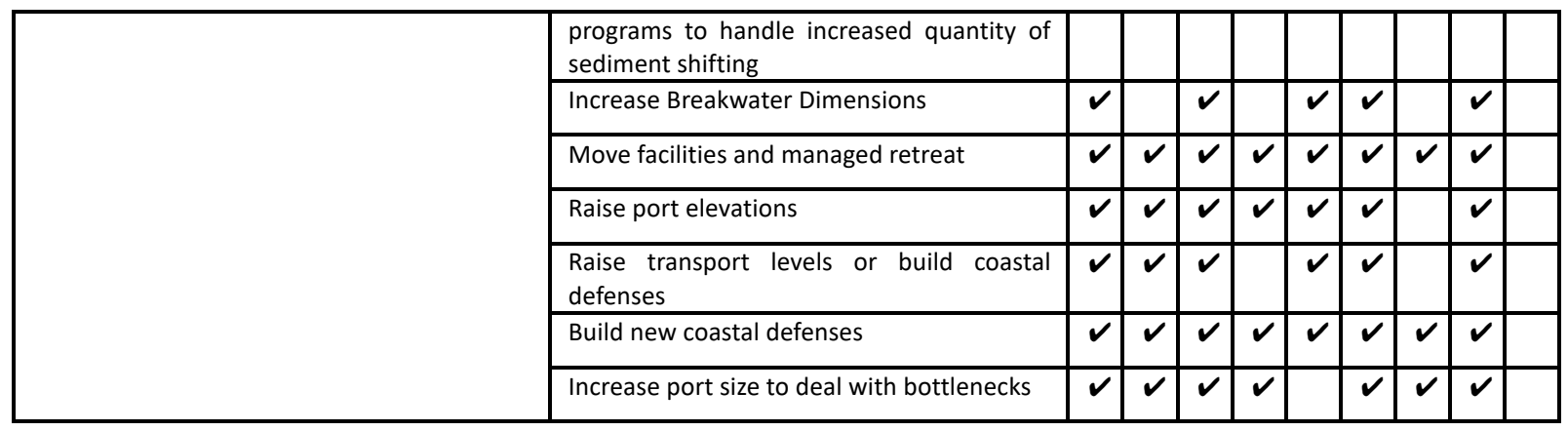

As impacts of climate change become more profound, many port communities will need to consider more transformational adaptation strategies ${ }^{93,95}$. For example, there are three major adaptation responses to sea level rise: elevate, defend, or retreat ${ }^{93,96,97}$. Elevating a port typically entails raising the port above the floodplain, reconstructing facilities at the new elevation, and designing a system to accommodate the difference in heights between the water level and the port infrastructure ${ }^{98}$. Defending a port entails construction of a coastal protection solution, such as a caisson breakwater, often with floodgates or locks to allow for the passage of ships ${ }^{99}$. In areas where adjacent land is not available for development, ports can expand by filling in submerged land to a sufficient elevation that will also protect existing infrastructure. Retreat will likely be the option of last resort because adjacent hinterland areas are typically not vacant or available for relocation, and regional economies depend heavily on their local port. Unless a protected deep river or estuary is available, most ports will likely either occupy their current location or be abandoned, perhaps in favor of consolidation into a larger regional "super-port". Regardless of which overall strategy (or strategies) port decision makers choose, climate change adaptation to sea level rise - whether through elevation, defense, or re-construction of infrastructure - will need to draw upon a wide variety of technological, engineering, design/maintenance, planning, insurance, and management options (Table 2) and engage many stakeholders in the process.

While implementing resilience strategies will no doubt be costly, some ports may find that resilience provides a competitive advantage. Shippers may be more comfortable investing in a "climate-ready port," for example. Extreme events would likely result in far less damage to port property and to the surrounding environmental and communities. Also, insurance premiums might also be lower for ports with lower risks. On the other hand, ports need to consider that many resilience investments will simply buy them time, but not solve the ultimate problem. For example, a port might invest in a one-meter sea level rise solution, but eventually sea levels will likely continue to rise well beyond one meter. Thus, investments in resilience for a port should be thought of as stop-gap measures that will allow for continued operation until a certain threshold is exceeded. Finally, the resilience measures considered for a given port must be considered within the context of its supply chain and surrounding community. A resilient port is only as resilient as the weakest link in its connecting roads, rails, pipelines and other critical infrastructure. 


\begin{tabular}{|c|c|}
\hline & Adaptation Action \\
\hline \multirow{4}{*}{ 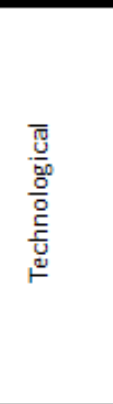 } & $\begin{array}{l}\text { As extreme weather events become more frequent, more targeted investment in technology that } \\
\text { expands the operating boundaries of equipment, for example, cranes that safely operate under } \\
\text { stronger wind gusts. }\end{array}$ \\
\hline & $\begin{array}{l}\text { To address increased temperatures, alter refrigerated storage specifications to meet demands of } \\
\text { temperature changes and seek less energy intensive alternatives. }\end{array}$ \\
\hline & $\begin{array}{l}\text { Onsite renewable and low emission energy for a range of functions, to avoid risks associated with } \\
\text { power disruption, the increased cost of energy and environmental legislative requirements. Some of } \\
\text { this is already happening, for example, fuel cells to power mobile logistics elements and to cool } \\
\text { refrigerated cargo, and photovoltaic cells to generate administrative building power requirements. }\end{array}$ \\
\hline & $\begin{array}{l}\text { Automation of logistics procedures is already being undertaken at some ports, and this process is } \\
\text { expected to continue. }\end{array}$ \\
\hline \multirow{7}{*}{ 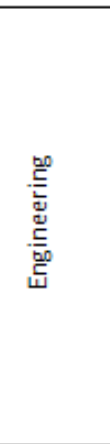 } & $\begin{array}{l}\text { Future procurement of assets such as gantry loaders, conveyor belts, shore cranes etc. needs to be } \\
\text { assessed against future operating environment requirements. That is, the expected life of the } \\
\text { equipment, and anticipated future climate it needs to operate in, needs to be considered. }\end{array}$ \\
\hline & Storage facilities may need to be upgraded to accommodate more extreme events. \\
\hline & $\begin{array}{l}\text { Assess and upgrade drainage systems to cope with projected intense rain events (potentially work in } \\
\text { partnership with city governments for this option). }\end{array}$ \\
\hline & Ongoing hydrographical monitoring, to identify if dredging requirements need to be modified. \\
\hline & $\begin{array}{l}\text { More robust dust suppression systems may be required (such as covering coal stockpiles, rather than } \\
\text { just dampening) }\end{array}$ \\
\hline & \\
\hline & Roadways in, and through the ports may need to be raised to respond to flooding issues. \\
\hline \multirow{3}{*}{ 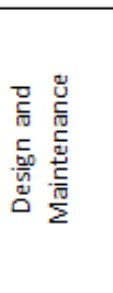 } & $\begin{array}{l}\text { Encouraging modal shift to improve resilience by introducing elements of redundancy into the supply } \\
\text { system; that is, removing the reliance on EITHER rail OR road, but looking at better incorporation of } \\
\text { the two. }\end{array}$ \\
\hline & $\begin{array}{l}\text { Ensure climate changes are included in future design specifications, including accommodating future } \\
\text { rainfall requirements into new building designs, incorporating sea level rise and storm surge into all } \\
\text { port infrastructure elements. }\end{array}$ \\
\hline & $\begin{array}{l}\text { Ensure ports have a proactive infrastructure and asset management plan that considers asset lifecycle } \\
\text { elements, including altered materials deterioration regimes. }\end{array}$ \\
\hline \multirow{2}{*}{ 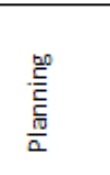 } & $\begin{array}{l}\text { Working in partnerships with city governments and supply chain logistics infrastructure providers to } \\
\text { appropriately plan and design connected logistics hubs, resilient to the impacts of climate change } \\
\text { relevant for the area. }\end{array}$ \\
\hline & Investigate diversification of trade into climate resilient commodities. \\
\hline 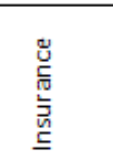 & $\begin{array}{l}\text { Some risks cannot be mitigated, and instead, the risk may need to be outsourced to a third party, } \\
\text { through purchasing insurance. Working collaboratively with insurance providers to determine the } \\
\text { quantitative elements of climate risk will assist ports to appropriately insure against risks they are } \\
\text { unable to reduce. }\end{array}$ \\
\hline \multirow[t]{2}{*}{ 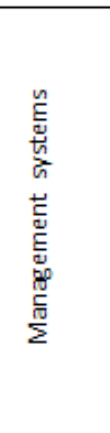 } & $\begin{array}{l}\text { The range of systems that could incrementally introduce climate considerations includes } \\
\text { environmental, OHS, emergency and risk management systems. } \\
\text { - Updating policy elements across the management systems to include consideration of } \\
\text { - climate change impacts } \\
\text { - Incorporate training on climate change, as part of ongoing system training elements } \\
\text { - } \quad \text { relevanter to individual ports. } \\
\text { - Update legal compliance elements regularly. }\end{array}$ \\
\hline & $\begin{array}{l}\text { Develop pandemic plans as part of the emergency preparedness and response system. This was } \\
\text { discussed as an opportunity particularly for the more northern ports, as vector and water-borne } \\
\text { diseases become a more likely threat. }\end{array}$ \\
\hline
\end{tabular}




\subsection{Barriers to adaptation}

Ports around the world are arguably only at the beginning of understanding the full range of potential solutions to the climate change challenge ${ }^{8}$ and public examples of strategy implementation, monitoring, and revision still remain few and far between ${ }^{101}$. There are many reasons that can explain why ports have not yet successfully introduced substantive adaptation measures for future climatic conditions. Some of the key barriers portrayed in the literature are described next.

\section{Working with uncertainty}

Uncertainty is an inherent element of future climate risk assessments. As so many factors are outside a port's control and may also change in the future (including non-climate factors), it can be difficult to assess the effectiveness and appropriateness of individual adaptation actions. Uncertainty is inherent in future climate projections, and the lack of availability of projections at the local level can lead decision-makers to defer actions until there is more certainty in projections. Ultimately, better understanding the vulnerability of ports will lead to impetus for adapting ports and port systems to new climate regimes ${ }^{102}$.

\section{Long timescales}

As mentioned earlier, one of the main challenges of climate adaptation for ports is that many future climate change impacts may fall outside the planning horizon of the ports, but investment in longlived assets needs to be considered now (particularly in the case of hard infrastructure).

\section{Multiple stakeholders and fragmented decision systems}

Simply defining the system of concern can be a significant challenge. A port authority may have jurisdiction over its own land, but as a part of a supply chain there are many stakeholders impacted by its decisions. A port is typically one part of a harbor that involves numerous private businesses, public agencies, community groups, and the public. Many have overlooked the fact that port operations are largely a business activity in which decision-making is closely knit with multiple stakeholders. The attitudes of port decision-makers (policymakers, private, terminal operators, and others) about how climate change impacts should be addressed - given time and budgetary constraints - will shape the planning approach, process, and outcomes. Why should a private terminal operator invest in items that would mainly benefit the future holders of the concession ${ }^{103}$ ? In addition, it is not always clear which stakeholder is best positioned to champion a large-scale resilience project that benefits a region.

\section{Defining appropriate measures of success}

A direct consequence of long timescales for climate risks and resilience measures can be the issue of correctly assigning costs and benefits to a particular adaptation action over time. The same challenge exists for the monitoring and evaluation of resilience investments, e.g., building new berths to higher levels to accommodate projected sea-level rise. Several studies have elaborated on some of the core principles that underpin effective adaptation ${ }^{89,104}$. This challenge encompasses both the selection of appropriate metrics for monitoring performance, as well as the definition of "success". 
A successful adaptation initiative needs to encompass the principles outlined earlier, as well as being equitable, efficient and effective. How will unintended impacts be measured to determine if the initiative was a "success" for the port, and other stakeholders? More research is needed to develop appropriate adaptation indicators for ports. As part of a good monitoring and evaluation process, ports need to determine the purpose of the evaluation at the outset. Importantly, ongoing learning is an important aspect of adaptation, and should be considered the initial planning stage. When undertaking (unprecedented) adaptation planning, many ports choose to go it alone with limited consultation with other stakeholders or the public, based on established planning approaches based on short term political and economic priorities ${ }^{105}$.

\section{Cost of adaptation}

Finally, given the difficulty in defining the problem, port decision-makers are often 'half-hearted' about implementing effective adaptation strategies, especially under budgetary constraints and imperfect information, even if they are well-aware of the potential (negative) impacts that climate change can bring to effective port operations and the necessity for action ${ }^{106}$. With many solutions requiring investment on the scale of hundreds of millions or even billions of US dollars, a port authority or other individual stakeholders will simply not be able bear the cost without significant assistance from a national government or outside investor. Though there are new financing structures such as public/private partnerships being proposed, there are still few places to look for best practices to fund major resilience investments ${ }^{107}$.

\section{Application: examples of adaptation and resilience studies}

In the past decade, collaborations between academics and practitioners have begun to address climate risks to ports on both a multi-port and single port case study scale. Both approaches play an important role in developing an understanding of adaptation implications on the local, regional, and global scale. This section discusses a variety of approaches and summarizes some of the key strategies and approaches undertaken by ports around the world.

\subsection{Multi-port studies}

Multi-port studies so far have focused on the broadest quantification of both the risks to ports and the costs associated with adaptation. Perhaps the first global study of port adaptation consisted of a global survey of port authorities conducted in $2010^{8}$. This study demonstrated a high level of concern amongst port authorities, the lack of action at that point, and provided a baseline from which future work specific to ports could develop. Regional, national, and global studies specific to port climate assessment are still in a nascent stage. A review of such approaches by Mclntosh and Becker discusses many of the difficulties inherent in quantifying concepts such as "resilience" and "vulnerability" that are, in and of themselves, directly immeasurable ${ }^{108}$. Such studies rely on expert input and the use of "indicators" that serve as proxies for these fuzzy concepts.

Though focused at the "port city" scale, Nicholls et al ${ }^{109}$ established the magnitude of the challenge of coastal cities throughout the world, finding that by 2070 the exposed assets in 136 large port cities could grow to $\$ 35$ billion (more than ten times today's exposure), if climate change is left unchecked. 
This study used indicators such as elevation, population, water levels, and values of assets, to arrive at an estimate for exposed assets.

One of the more direct effects of climate-related events on port operations is the shutdown of port operations resulting from storm events. On a regional scale, Esteban et $a l^{110,111}$ looked more closely at the details of port downtime in Vietnam and Japan. Their work suggests that a $10 \%$ increase in typhoon intensity can result in between $18 \%$ and $43 \%$ more downtime for Japanese ports, resulting in significant costs to the national economy. Chhetri et $a l^{112}$ expand on this approach using a Container Terminal Operation Simulation (CTOS). This simulates the operations of port operational assets such as cranes, straddle carriers, and trucks to observe the individual and collective behavior under various extreme weather events using a set of Key Performance Indicators (e.g., crane rates, straddle productivity, truck queue length, yard utilization).

Another study looked at the consequences of adaptation and modeled the resource materials required to protect the world's most important ports. Findings suggest that approximately 436 million cubic meters of construction materials, including cement, sand, aggregate, steel rebar, and riprap would be required to build dikes around ports as defense against a 2 meter sea level rise $^{113}$. This study underscores the importance of considering adaptation both locally and globally, as the implications of adapting many ports (or other coastal infrastructures) can be far-reaching in terms of supply and demand for physical resources.

\subsection{Local port case studies}

Single port studies vary in their approaches and usually rely on expert judgments from members of a given port community. The impacts of climate change vary significantly across countries and regions and the intensity of its effects will also vary over time depending both on natural climate variation and the degree of anthropogenic warming of the atmosphere. Thus, translation of climate science into formats suitable for port authorities is a critical part of the adaptation process, and emphasizes the need for collaboration between ports and scientists. Port authorities must be able to manage both the natural variations in the climate at their port, which are generally understood as existing within known parameters, and a climate that is changing in potentially new ways.

Ports have conducted climate assessments or adaptation planning efforts using a variety of methodologies (examples in Table 3). One approach -- a resilience index developed in the USA -assists port authorities in taking a critical look at their own vulnerabilities ${ }^{87}$. Piloted with the ports of Pascagoula (FL), Lake Charles (LA), and Corpus Christi (TX), the approach facilitates a participatory process that helps various stakeholders recognize priority risks through a self-directed questionnaire. The Port of San Diego (CA) in the US coupled an adaptation planning process with a climate mitigation approach in their Climate Mitigation and Adaptation Plan (CMAP) ${ }^{78}$. The process proved challenging, as it was far more difficult to find consensus around adaptation milestones and metrics than it was for mitigation metrics (in the end, the Port suspended the adaptation plan, but adopted the mitigation plan). Another study in the USA facilitated a robust stakeholder dialogue around longterm planning options for the Port of Providence (Rhode Island). This approach did not quantify port vulnerabilities, rather it engaged stakeholders in exercises that allowed them to identify the 
complexities of resilience planning in order to plant the seed for future decision making ${ }^{114}$. 
Table 3 - Examples of local port climate and vulnerability assessments

\begin{tabular}{|c|c|c|}
\hline Port Name & Assessment Name & Lead \\
\hline $\begin{array}{l}\text { Avatiu Port, (Roratunga, Cook } \\
\text { Island) }\end{array}$ & $\begin{array}{l}\text { Climate Risk Assessment for Avatiu } \\
\text { Port and Connected Infrastructure }\end{array}$ & $\begin{array}{l}\text { University of New South Wales Water } \\
\text { Research Laboratory }\end{array}$ \\
\hline Port of Felixstowe, (Suffolk, UK) & $\begin{array}{l}\text { Climate Change Adaptation Report } \\
\text { Felixstowe Dock and Railway } \\
\text { Company August } 2015\end{array}$ & $\begin{array}{l}\text { Hutchison Ports UK Environmental } \\
\text { Committee }\end{array}$ \\
\hline $\begin{array}{l}\text { Meulles el Bosque, Cartagena } \\
\text { (Columbia) }\end{array}$ & $\begin{array}{l}\text { Climate Risk and Business Ports } \\
\text { Terminal Maritimo Muelles el } \\
\text { Bosque Cartagena Columbia }\end{array}$ & International Finance Corporation \\
\hline Port of Seattle (WA, USA) & $\begin{array}{l}\text { Planning for Sea Level Rise: The } \\
\text { Current State of science, } \\
\text { vulnerability of port of Seattle } \\
\text { Properties to sea level rise, and } \\
\text { possible Adaptation strategies }\end{array}$ & Port of Seattle \\
\hline Port of San Diego (CA, USA) & $\begin{array}{l}\text { Climate change and sea level rise } \\
\text { impacts at ports and a consistent } \\
\text { methodology to evaluate } \\
\text { vulnerability and risk }\end{array}$ & Port of San Diego, CA \\
\hline $\begin{array}{l}\text { Port of New York and New } \\
\text { Jersey (USA) }\end{array}$ & $\begin{array}{l}\text { Case Study: Assessment of the } \\
\text { Vulnerability of Port Authority of } \\
\text { NY \& NJ facilities to the Impacts of } \\
\text { Climate Change }\end{array}$ & $\begin{array}{l}\text { Rockefeller Foundation and NY City Panel } \\
\text { on Climate Change }\end{array}$ \\
\hline Port of Hamburg (Germany) & $\begin{array}{l}\text { IAPH-Report on Seaports and } \\
\text { Climate Change and } \\
\text { Implementation Case Study for the } \\
\text { Port of Hamburg }\end{array}$ & Hamburg Port Authority \\
\hline Port Kembla (Australia) & $\begin{array}{l}\text { Seaport Resilience to Climate } \\
\text { Change: mapping vulnerability to } \\
\text { sea level rise }\end{array}$ & $\begin{array}{l}\text { National Climate Change Adaptation } \\
\text { Research Facility (NCCARF), RMIT } \\
\text { University School of Business, The } \\
\text { University of Queensland }\end{array}$ \\
\hline Port Louis (Mauritius) & $\begin{array}{l}\text { Sub-Saharan African Cities: A five- } \\
\text { City Network to Pioneer Climate } \\
\text { Adaptation through participatory } \\
\text { research and local action }\end{array}$ & $\begin{array}{l}\text { International Development Research } \\
\text { Council and Department for International } \\
\text { Development }\end{array}$ \\
\hline $\begin{array}{l}\text { Thessalonica Container Terminal } \\
\text { (Greece) }\end{array}$ & $\begin{array}{l}\text { A Risk Assessment Methodology in } \\
\text { Container Terminals: The Case } \\
\text { Study of the Port Container } \\
\text { Terminal of Thessalonica, Greece }\end{array}$ & $\begin{array}{l}\text { Department of Maritime Studies, } \\
\text { University of Piraeus }\end{array}$ \\
\hline Port of Manzanillo (Mexico) & $\begin{array}{l}\text { Port of Manzanillo Climate Risk } \\
\text { Management }\end{array}$ & $\begin{array}{l}\text { International Finance Corporation, World } \\
\text { Bank Group }\end{array}$ \\
\hline $\begin{array}{l}\text { Port Kembla, Gladstone Port, } \\
\text { Port of Sydney (Australia) }\end{array}$ & $\begin{array}{l}\text { Understanding future risks to ports } \\
\text { in Australia, Enhancing the } \\
\text { resilience of seaports to a changing } \\
\text { climate }\end{array}$ & $\begin{array}{l}\text { RMIT University } \\
\text { Queensland }\end{array}$ \\
\hline Port of Providence & $\begin{array}{l}\text { Hurricane Resilience: Long Range } \\
\text { Planning for the Port of Providence }\end{array}$ & $\begin{array}{l}\text { University of Rhode Island and RI Dept. of } \\
\text { Transportation }\end{array}$ \\
\hline
\end{tabular}

Elsewhere, the UK Climate Change Act 2008 invited Port Authorities with a throughput of more than 
10 million tons of commercial cargo (annually) to prepare a report on the current and future predicted impacts of climate change on their organization and their proposals for adapting to climate change. As a result of this Act, there were eight publicly available port authority adaptation plans at the time this paper was drafted, five of which to date were revised and updated in $2015^{115}$. In Australia, a study of climate futures for the Port of Gladstone entailed the use of several different Global Climate Models (GCMs) to model a range of variables that were not all available either in one individual model or in a compatible ensemble of models. This approach added to the complexity and richness of the result ${ }^{42,100}$.

The Port of Rotterdam (NL), one of the biggest ports in the world, has a pro-active plan for dealing with the consequences of climate change. Currently the city and the Port have flood protection in place rated at managing a one-in-10,000-year flood event. The old port is also being redeveloped into new, sustainable areas for living, working, education and recreation. This work is undertaken as part of the C40 "Connecting Delta Cities" network ${ }^{116,117}$. Two further illustrative examples of industry-leading risk and adaptation assessments from Canada and Colombia can be found in Boxes 2 and 3. 
Port of Vancouver (POV) is the largest port in Canada in terms of tonnage (Figure 3$)^{118}$. Located along the Pacific coastline, shocks to its operation pose substantial impacts on the city of Vancouver, the Province of British Columbia (BC), and Canada as a whole ${ }^{119}$. POV and its facilities face threats from climate-related flooding from the Fraser River, and a serious flood event may cause the city of Vancouver billions of dollars in terms of economic damage ${ }^{120}$. POV has undertaken adaptation planning since the early 2010s, but has yet to define or establish an appropriate approach and relies on regional collaborative efforts, such as the Coastal Flood Risk Assessment (through the Climate Change Adaptation Strategy adopted by the city of Vancouver in 2012) and Lower Mainland Flood Management Strategy (initiated and coordinated by the Fraser Basin Council (FBC) in 2014). Both attempt to understand the current and future scenarios for the sake of more effective adaptation planning, but find it difficult to proceed to the 'implementation stage'.

The first challenge is a lack of consensus around funding and leadership. No regional stakeholders are proposing significant action plans and questions around jurisdictional responsibilities also pose additional barriers. However, if the Canadian Federal Government takes the lead, its common funding standard may not apply to all stakeholders, not to mention to the sensitive issue of fairness to different provinces. Unsurprisingly, the result is 'wait and see'. The second challenge is the focus on physical works with (comparative) negligence on costs. Port stakeholders overwhelmingly favour protection when tackling flood risks. Although the British Columbia Provincial Government (BCPG) dedicate some funds to the municipalities for this purpose, they require the latter to share up to $33 \%$ of the costs in capital works. This discourages many municipal authorities from participating ${ }^{121}$. This raises the third challenge - the institutional problem of adaptation. BCPG follows its typical approach in infrastructure funding: upper levels of the hierarchy devolve responsibility to the lower levels, but it is only when the local authorities agree to undertake responsibilities (in terms of ownership, operation, and maintenance) that a project would actually proceed. This suggests that the emphasis on the physical approach to adaptation may make the financial and institutional constraints even more explicit.

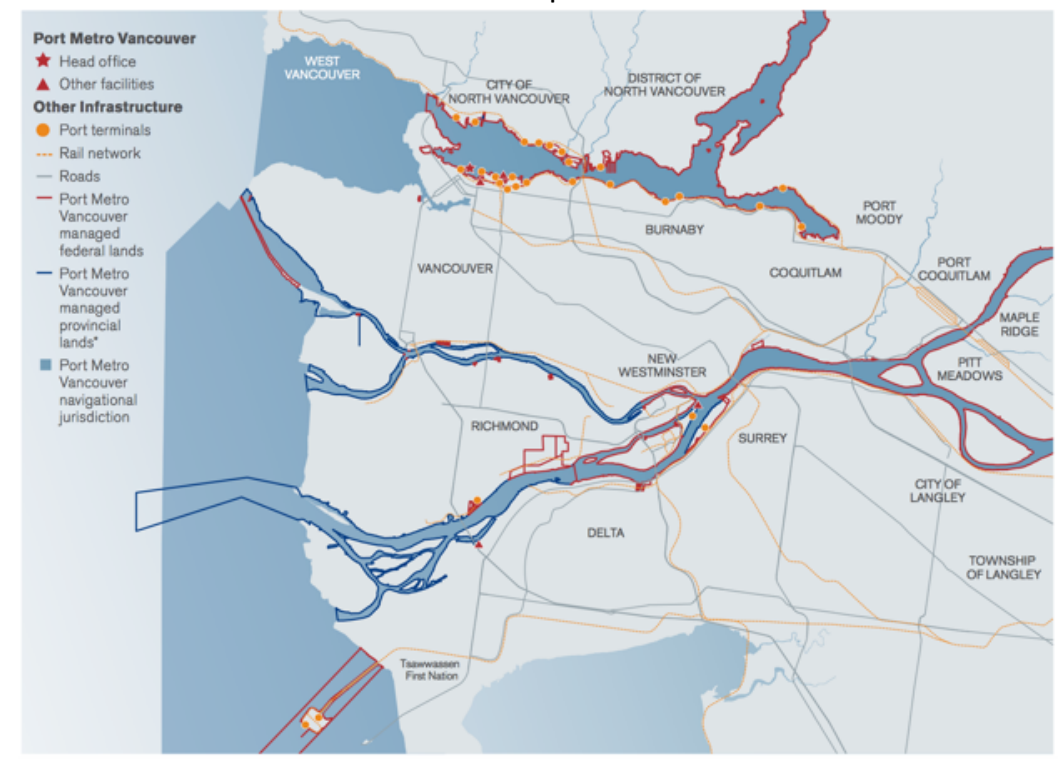

Figure 3 - Jurisdiction map of Port of Vancouver, Canada ${ }^{104}$

Box 2 - Spotlight on Port of Vancouver, CA 
A study in Colombia by The World Bank assessed the climate change risks to the whole port system (Figure 4), with the ain of providing a case study for other ports and authorities to follow. It centered on the following questions:

- What risks and opportunities do climate change present for the port?

- What are the most significant risks for the port?

- How could the port manage climate change risks in the most economically optimal way, taking account of environmental and social objectives?

- How could climate-related opportunities be developed and exploited?

- Where could the port work in collaboration with other stakeholders to manage climate risks?

-What tools and techniques for climate risk assessment and management can be applied to understand these issues?

This is one of the few studies that combines an analysis of the potential effect of climate change on the port infrastructure, its supply chains and the business of the port. It recommends a range of adaptation options that include: for port infrastructure - paving parts of the port, improving drainage and raising the height of storage warehouses; for supply chains - raising the height of access roads; for business - investing in development of trade in 'climate resistant commodities' and increasing insurance.

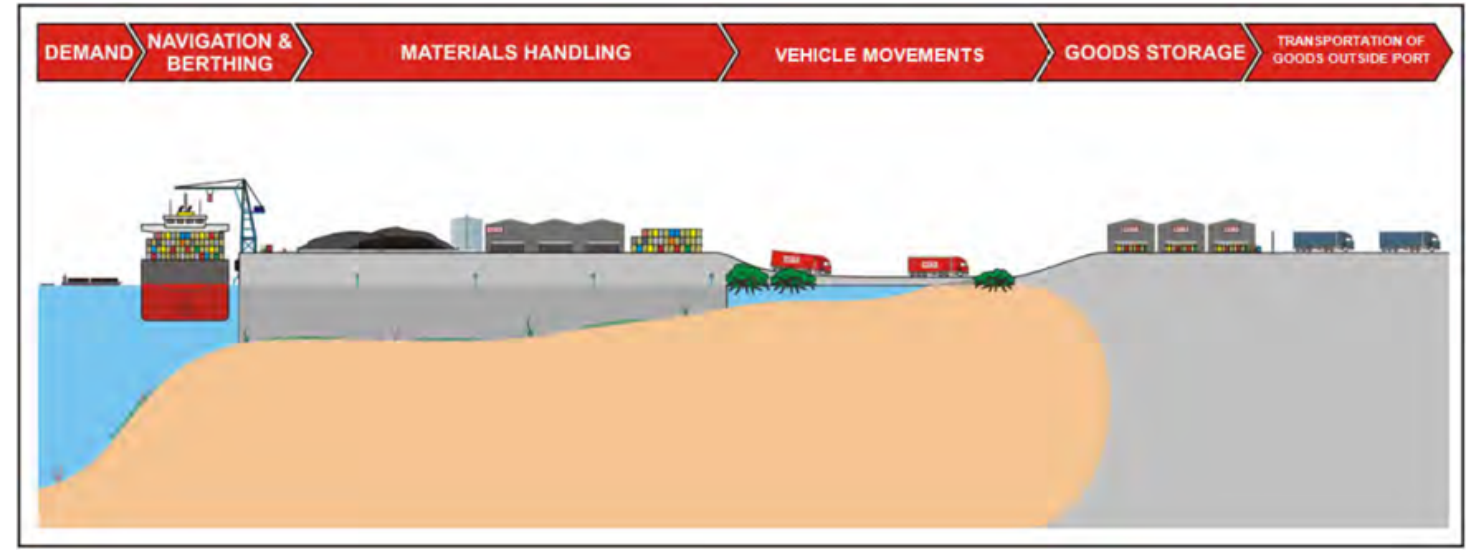

Figure 4 - Conceptual model of a port and the main activities affected by climate change. Diagram from the International Finan Corboration. World Bank. 2011 studv of Terminal Maritimo Muelles el Bosaue. Cartaaena. Colombia ${ }^{74}$

Box 3 - Spotlight on Muelles el Bosque, Columbia

\section{6 - Concluding remarks, recommendations, and next steps}

As climate change risks have become increasingly recognized and understood by the scientific community, vulnerable sectors such as shipping, ports, and supply chains are now beginning to consider implications for both for their long-lived infrastructure and the efficiency and resilience of their operations. Climate change will likely emerge as one of the most complicated and expensive environmental challenges that modern society has faced. Though the major drivers for ports will be from sea level rise, storm events, and heavy precipitation, other climate impacts will also take a toll. For example, an increase in heat events might affect worker productivity or energy consumption of chillers and refrigeration units. Ports in flat low-lying areas will face a greater challenge than those in areas with steeper terrain that can more easily accommodate the construction of a storm barrier. Also, while sea level rise may help some ports to accommodate deeper draft vessels, it also could cause an increase in the rate of sedimentation leading to some dredged channels to require more frequent maintenance. The financing of major resilience 
enhancements will also prove daunting. While many larger ports may be able to implement incremental strategies, such as elevating their infrastructure or building barriers ${ }^{113,122}$, many of the world's smaller ports may not have the resources to take on this scale of project. Some nations may look toward consolidating port infrastructure, which could cause some coastal areas to lose their local port functions to a larger (and more protected) port in their region. Finally, while there is an increase of research attention on the climate resilience of port systems, there is still a scarcity of literature on the wider impacts affecting supply chains

Our review of scientific and grey literature found that while a significant number of international ports are increasingly cognizant of the challenges and opportunities posed by climate change, a much smaller number have taken the next step and developed and then implemented strategies specifically designed to address climate change or alternatively mainstreamed climate change considerations into existing risk management plans, often seen as the most desirable course of action by port authorities.

Our findings closely mirror many of the issues addressed at a United Nations Conference on Trade and Development's (UNCTAD) Ad Hoc Expert Meeting on climate change and port adaptation (2011), one of the first such meetings of its kind. Participants highlighted the importance of obtaining reliable information that provides clear insight on how climate change risks would impact port facilities and operations, and thus the quality of a port's strategic planning ${ }^{123}$. New, innovative approaches should be developed that reduce uncertainties and clarify priorities, while catalyzing a transformative adaptation process ${ }^{124}$. Threatened uses (e.g., ports and port infrastructures) must develop plans and actions that can be applied into a normative, historically contingent and economically sensible context, and enhance capacities and resilience to (diversified) climate change impacts in the long term. Such planning is particularly important for developing nations and Small Island Developing States that depend on ports as lifelines for island economies.

Adaptation measures will involve infrastructure, supply chains, and people. It will consist of both process (changes to practice, knowledge management etc.) and physical outcomes (actions such as flood defenses). As adaptation planning and implementation evolve, the port community will benefit from continued dissemination of progress, lessons learned, and methods to evaluate the effectiveness of various alternatives. Suggestions culled from the literature for the development of research and adaptation guidelines in support of climate resilient ports include:

- Ensure executive level understanding and commitment to adaptation;

- Build or secure appropriate technical capability - to undertake climate risk assessments, and to assist with implementing adaptation options, and ongoing monitoring;

- Work in partnership - climate impacts do not respect borders, working with relevant partners contributes to more effective outcomes; building "regional redundancy" capacity can help damaged ports bounce back from storm events more quickly by accessing resources (e.g., equipment, cargo rerouting) at nearby facilities.

- Understand risks and thresholds both for the short term and the long term - ideally identified and analyzed through some form of risk assessment process; 
- Support the risk assessment by monitoring, recording and analyzing data at the port site (particularly measurement of key climate variables and of course sea levels).

- Employ adaptive management principles to cope with uncertainty - that is, iterative decision-making, incorporating feedback, and testing / updating of assumptions;

- Look for "no/low regrets" and "win-win" adaptation options - those that as well as reducing the risks of climate change impacts, help produce other benefits; in particular, encourage / promote the concept of an adaptation pathways approach for sea ports that encourages planners to consider a number of defined possible future scenarios (see, for example, the Thames Barrier ${ }^{102,125,126}$ )

- Avoid "maladaptation" - or actions that limit future adaptation options;

- Ensure adaptation measures are equitable - the effects of different adaptation efforts, and the costs should be considered across different groups/sectors;

- Develop new tools for objective multi-port assessment of port vulnerability that complement the self-assessments discussed in this paper. As adaptation resources will likely be scarce, decision-makers need criteria to help evaluate priorities for resilience investments that project the public, as well as private, interest ${ }^{108}$.

On every scale, from specific organizations ${ }^{127}$ to nations as a whole ${ }^{128}$, adaptation involves multiple actors, policies, and practices and requires communication and public engagement to ensure success ${ }^{101}$. Policymakers and port practitioners will benefit from decision support whether through knowledge, innovative tools, ideas, and guidelines - to effectively respond to the climate change challenges for ports, transportation, and supply chains. Simultaneously, individual scholars and research efforts will benefit from access to appropriate personnel for data and information collection. Scientists and academics have an important role to play in such multistakeholder networks. Firstly, they can help to define the problem, by enhancing port authorities understanding of climate change and future risks, both theoretically and through empirical evidence. Second, they can support the development of robust strategies and practices that adapt to climate change and build in long term resilience. Third, through research, they can contribute the latest scientific knowledge directly through these networks.

Thus, a partnership approach between research and practice can and should be leveraged to address these challenges so as to effectively adapt ports to climate change. A partnership approach can create an integrated knowledge base and management system, and add value to port stakeholders' efforts and building the capacity to address climate change impacts. Forming partnerships can serve as the pioneering step towards transnational collaborative networks between port stakeholders around the globe, encouraging mutual trust among stakeholders from different sectors, countries and regions. In addition, it facilitates knowledge and information flows and establishes 'common stories' that address a growing global problem, with strong local perspectives and interests. Information exchange through partnerships allows scholars, policymakers and industrial practitioners to compare their local approaches to international practices. For example, assessment tools can demonstrate to the broader port, transportation, logistical and supply chain communities how well particular elements are functioning. Partnerships can also lead to unified data collection and dissemination, alleviating the burden of 
filling in the same data for diversified purposes. Scholars, policymakers, and industrial practitioners, should engage in new collaborations to better understand the priority risks and to identify and implement options that will enhance the resilience of their facilities and operations.

Finally, and perhaps most importantly, we recommend engaging a wide range of stakeholders into dialogue around adaptation. Planning for large-scale change requires years or even decades of discussion, assessment, and decision-making. The magnitude of potential changes suggests that major investments will be needed to properly adapt many port areas. Since ports and supply chains make such strong contributions to the economy, many sectors of society will pay the price if ports are not properly adapted to new environmental conditions. Thus, communication about port resilience must extend far beyond the port and terminal operators themselves to include environmental advocates, politicians, and the general public.

\section{Acknowledgements}

This paper is a companion paper to $\mathrm{Ng}$ et al. (forthcoming) published in the same journal.

\section{Reference:}

Ng, A.K.Y., Andrews, J., Babb, D., Lin, Y. and Becker, A. (forthcoming): 'Impacts of climate change for shipping: opening the Arctic seas'. Wiley Interdisciplinary Reviews: Climate Change (in press).

\section{END}




\section{References}

1. NGIA (National Geospatial-Intelligence Agency). World Port Index, 23rd Edition. 2014. Available at: http://msi.nga.mil/MSISiteContent/StaticFiles/NAV_PUBS/WPI/Pub150bk.pdf.

2. Baird AJ. Public goods and the public financing of major European seaports. Maritime Policy \& Management 2004, 31:375-391.

3. Goss R. Economic policies and seaports: The economic functions of seaports $\dagger$. Maritime Policy and Management 1990, 17:207-219.

4. AAPA (American Association of Port Authorities). Talking Points: United States Seaports and Job Creation. 2015. Available at: http://aapa.files.cms-plus.com/PDFs/U S Seaports and Job Creation 5-12-2015.pdf.

5. Reeve D. On the Impacts of Climate Change for Port Design. 26th International Conference for Seaports \& Maritime Transport "Integration For a Better Future " 2010.

6. Thoresen CA. Port designer's handbook: recommendations and guidelines: Thomas Telford Services Ltd; 2003.

7. Losada M, Benedicto M. Target Design Levels for Maritime Structures. Journal of Waterway, Port, Coastal, and Ocean Engineering 2005, 131:171.

8. Becker A, Inoue S, Fischer M, Schwegler B. Climate change impacts on international seaports: knowledge, perceptions, and planning efforts among port administrators. Climatic Change 2012, 110:5-29.

9. IPCC (Intergovernmental Panel on Climate Change). Managing the risks of extreme events and disasters to advance climate change adaptation. Special report of the Intergovernmental Panel on Climate Change. Cambridge, UK, and New York, NY, USA; 2012.

10. ABM \& CSIRO (Australian Bureau of Meteorology and CSIRO). Climate Change in the Pacific: Scientific Assessment and New Research. Volume 1: Regional Overview. 2011.

11. Heaver TD. The evolving roles of shipping lines in international logistics. International Journal of Maritime Economics 2002, 4:210-230.

12. Ng A, Liu J. Port-focal logistics and global supply chains: Springer; 2014.

13. Miyashita K. Logistics strategy of Japanese ports: The case of Kobe and Osaka. World Shipping and Port Development. Palgrave-Macmillan: Basingstoke 2005:181-198.

14. Bichou K, Gray R. A logistics and supply chain management approach to port performance measurement. Maritime Policy \& Management 2004, 31:47-67.

15. Martin J, Thomas BJ. The container terminal community. Maritime Policy \& Management 2001, 28:279-292.

16. IAPH (International Association of Ports and Harbors Port Planning and Development Committee). Seaports and Climate Change - An Analysis of Adaptation Measures -. 2010.

17. Bender MA, Knutson TR, Tuleya RE, Sirutis JJ, Vecchi GA, Garner ST, Held IM. Modeled impact of anthropogenic warming on the frequency of intense Atlantic hurricanes. Science 2010, 327:454-458.

18. Tebaldi C, Strauss BH, Zervas CE. Modelling sea level rise impacts on storm surges along US coasts. Environmental Research Letters 2012, 7:014032. 
19. Von Storch H, Gönnert G, Meine M. Storm surges-An option for Hamburg, Germany, to mitigate expected future aggravation of risk. Environmental Science \& Policy 2008, 11:735-742.

20. Jonkeren O, Rietveld P, van Ommeren J, te Linde A. Climate change and economic consequences for inland waterway transport in Europe. Regional Environmental Change 2013:1-13.

21. Elsner JB, Kossin JP, Jagger TH. The increasing intensity of the strongest tropical cyclones. Nature 2008, 455:92-95.

22. Emanuel K. Increasing destructiveness of tropical cyclones over the past 30 years. Nature 2005, 436:686-688.

23. Haveman JD, Shatz HJ. Protecting the nation's seaports: Balancing security and cost. 2006.

24. EQECAT Inc. Post-landfall loss estimates - Hurricane Sandy - Nov. 1, 2012 (Insured Losses: \$10 - 20 Billion; Total Economic Damage: \$30 - 50 Billion). 2012. Available at: https://www.corelogic.com/about-us/news/corelogic-issues-2012-natural-hazardrisk-summary-and-analysis-highlighting-risk-in-years-biggest-disasters-across-u.s.aspx.

25. USCCSP (United States Climate Change Science Program). Impacts of Climate Change and Variability on Transportation Systems and Infrastructure: Gulf Coast Study, Phase I. A Report by the U.S. Climate Change Science Program and the Subcommittee on Global Change Research 2008. Available at: http://www.climatescience.gov/Library/sap/sap4-7/final-report/.

26. Smythe T. Assessing the Impacts of Hurricane Sandy on the Port of New York and New Jersey's Maritime Responders and Response Infrastructure. Quick Response Report No. 238: Final Report to the University of Colorado Natural Hazards Center 2013.

27. Rahmstorf S. A new view on sea level rise. Nature Reports Climate Change 2010:4445.

28. Parris A, Bromirsji, P., Burkett, V., Cayan, D., Culver, M., Hall, J., Horton, R.,, Knuuti K, Moss, R., Obeysekera, J., Sallenger, A.H., Weiss, J. Global Sealevel Rise Scenarios for the US National Climate Assessment. . NOAA Technical Report, National Oceanic and Atmospheric Administration 2012:37.

29. Horton BP, Rahmstorf S, Engelhart SE, Kemp AC. Expert assessment of sea-level rise by AD 2100 and AD 2300. Quaternary Science Reviews 2014, 84:1-6.

30. Vellinga P, Katsman C, Sterl A, Beersma J, Hazeleger W, Church J, Kopp R, Kroon D, Oppenheimer M, Plag H. Exploring high-end climate change scenarios for flood protection of the Netherlands. KNMI and Wageningen UR (Alterra, Earth System Science and Climate Change Group) 2008.

31. NRC (National Research Council). America's Climate Choices: Adapting to the Impacts of Climate Change. Washington, DC; 2010.

32. Vitousek S, Barnard PL, Fletcher CH, Frazer N, Erikson L, Storlazzi CD. Doubling of coastal flooding frequency within decades due to sea-level rise. Sci Rep 2017, 7:1399.

33. Kopp RE, Horton RM, Little CM, Mitrovica JX, Oppenheimer M, Rasmussen DJ, Strauss BH, Tebaldi C. Probabilistic 21st and 22nd century sea-level projections at a global network of tide-gauge sites. Earth's Future 2014, 2:383-406. 
34. Becker A, Matson P, Fischer M, Mastrandrea M. Towards seaport resilience for climate change adaptation: Stakeholder perceptions of hurricane impacts in Gulfport (MS) and Providence (RI). Progress in Planning 2014.

35. Blake ES, Gibney EJ, Landsea C. The deadliest, costliest, and most intense United States tropical cyclones from 1851 to 2010 (and other frequently requested hurricane facts). Washington, DC: NOAA/National Weather Service, National Centers for Environmental Prediction, National Hurricane Center; 2011.

36. PEER (Joint Legislative Committee on Performance Evaluation and Expenditure Review). The Impact of Hurricane Katrina on Mississippi's Commercial Public Ports and Opportunities for Expansion of the Ports. 2006. Available at: http://www.peer.state.ms.us/.

37. Esler S. Vanuatu: Post-Disaster Needs Assessment Report, Tropical Cyclone Pam, March 2015. 2015. Available at: https://www.gfdrr.org/sites/default/files/publication/PDNA_Cyclone_Pam_Vanuatu_Rep ort.pdf.

38. Lam JSL, Liu C, Gou X. Cyclone risk mapping for critical coastal infrastructure: Cases of East Asian seaports. Ocean \& Coastal Management 2017, 141:43-54.

39. Strauss-Wieder A. Superstorm Sandy Lessons Learned from a Major Port and Supply Chain Disruption. Transportation Research Board 2014. Available at: http://www.as-w.com/wp-content/uploads/2014-TRB-Sandy-Lessons-revised010114.pdf.

40. Ng A, Andrews J, Babb D, Lin Y, Becker A. Impacts of climate change for shipping: opening the Arctic seas. Wiley Interdisciplinary Reviews: Climate Change Forthcoming, In press.

41. Port Strategy. Chennai Port Operations Crippled by Floods. 2015. Available at: http://www.portstrategy.com/news101/world/asia/chennai-port-operations-crippledby-floods

42. McEvoy D, Mullett J, Millin S, Scott H, Trundle A. Understanding future risks to ports in Australia. Gold Coast, Australia National Climate Adaptation Research Facility, Gold Coast, Australia; 2013.

43. Chhetri P, Corcoran J, Gekara V, Maddox C, McEvoy D. Seaport resilience to climate change: mapping vulnerability to sea-level rise. Journal of Spatial Science 2014:1-14.

44. UK Environment Agency. The costs and impacts of the winter 2013 to 2014 floods Non-technical report. 2016. Available at: http://rpaltd.co.uk/uploads/report_files/thecosts-and-impacts-of-the-winter-2013-to-2014-floods-non-technical-report.pdf.

45. Marengo J. Climate change and extreme events in Brazil 2011. Available at: http://www.lloyds.com/ /media/f032df0f232f44be81c5b0827c4d91fd.ashx.

46. Lim-Camacho L, Plagányi ÉE, Crimp S, Hodgkinson JH, Hobday AJ, Howden SM, Loechel B. Complex resource supply chains display higher resilience to simulated climate shocks. Global Environmental Change 2017, 46:126-138.

47. Levermann A. Climate economics: make supply chains climate-smart. Nature 2014, 506:27-29.

48. Dyer J, Nguyen H, Chang Y, Enshaei H. How risk management fails to protect maritime supply chains through climate change risk impacts: A literature critique. In: Annual Conference of the International Association of Maritime Economists (IAME) 
2017; 2017.

49. IPCC. WGII AR5 Glossary. Fifth Assessment Report of the Intergovernmental Panel on Climate Change 2014.

50. IPCC (Intergovernmental Panel on Climate Change). Climate Change 2013. The Physical Science Basis. Working Group I Contribution to the Fifth Assessment Report of the Intergovernmental Panel on Climate Change. Summary for Policymakers. 2013. Available at: http://www.climatechange2013.org/images/uploads/WGI_AR5_SPM_brochure.pdf.

51. Whetton PH, Grose MR, Hennessy KJ. A short history of the future: Australian climate projections 1987-2015. Climate Services 2016.

52. Lovett GM, Burns DA, Driscoll CT, Jenkins JC, Mitchell MJ, Rustad L, Shanley JB, Likens GE, Haeuber R. Who needs environmental monitoring? Frontiers in Ecology and the Environment 2007, 5:253-260.

53. Holling CS. Resilience and stability of ecological systems. Annual Review of Ecology and Systematics 1973, 4:1-23.

54. Gere JM, Goodno BJ. Mechanics of materials: Nelson Education; 2012.

55. Davoudi S, Shaw K, Haider LJ, Quinlan AE, Peterson GD, Wilkinson C, Fünfgeld H, McEvoy D, Porter L, Davoudi S. Resilience: A Bridging Concept or a Dead End? "Reframing" Resilience: Challenges for Planning Theory and Practice Interacting Traps: Resilience Assessment of a Pasture Management System in Northern Afghanistan Urban Resilience: What Does it Mean in Planning Practice? Resilience as a Useful Concept for Climate Change Adaptation? The Politics of Resilience for Planning: A Cautionary Note. Planning Theory \& Practice 2012, 13:299-333.

56. Mileti DS. Disasters by design: A reassessment of natural hazards in the United States. Washington, DC, USA: National Academy Press; 1999.

57. Sánchez-Arcilla A, Jiménez J, Stive M, Ibañez C, Pratt N, Day J, Capobianco M. Impacts of sea-level rise on the Ebro Delta: a first approach. Ocean \& coastal management 1996, 30:197-216.

58. Schaeffer M, Hare W, Rahmstorf S, Vermeer M. Long-term sea-level rise implied by 1.5 degrees $\mathrm{C}$ and 2 degrees $\mathrm{C}$ warming levels. Nature Climate Change 2012, 2:867870 .

59. Jevrejeva S, Moore JC, Grinsted A. Sea level projections to AD2500 with a new generation of climate change scenarios. Global and Planetary Change 2012, 80:1420.

60. Liu J, Dietz T, Carpenter S, Alberti M, Folke C, Moran E, Pell A, Deadman P, Kratz T, Lubchenco J. Complexity of coupled human and natural systems. Science 2007, 317:1513.

61. Nicholls R, Hoozemans F. The Mediterranean: vulnerability to coastal implications of climate change. Ocean \& Coastal Management 1996, 31:105-132.

62. El-Raey M. Vulnerability assessment of the coastal zone of the Nile delta of Egypt, to the impacts of sea level rise. Ocean \& coastal management 1997, 37:29-40.

63. Shea EL, Dyoulgerov MF. Responding to climate variability and change: opportunities for integrated coastal management in the Pacific Rim. Ocean \& coastal management 1997, 37:109-121.

64. McGinnis MV, McGinnis CE. Adapting to climate impacts in California: the importance of civic science in local coastal planning. Coastal Management 2011, 
39:225-241.

65. Hanak E, Moreno G. California coastal management with a changing climate. Climatic Change 2012, 111:45-73.

66. Tobey J, Rubinoff P, Robadue Jr D, Ricci G, Volk R, Furlow J, Anderson G. Practicing coastal adaptation to climate change: lessons from integrated coastal management. Coastal Management 2010, 38:317-335.

67. Chemane D, Motta H, Achimo M. Vulnerability of coastal resources to climate changes in Mozambique: a call for integrated coastal zone management. Ocean \& coastal management 1997, 37:63-83.

68. Rosenzweig C, Solecki WD, Blake R, Bowman M, Faris C, Gornitz V, Horton R, Jacob K, LeBlanc A, Leichenko R. Developing coastal adaptation to climate change in the New York City infrastructure-shed: process, approach, tools, and strategies. Climatic Change 2011, 106:93-127.

69. Hanson S, Nicholls R, Ranger N, Hallegatte S, Corfee-Morlot J, Herweijer C, Chateau J. A global ranking of port cities with high exposure to climate extremes. Climatic Change 2010, 104:89-111.

70. Preston BL, Yuen EJ, Westaway RM. Putting vulnerability to climate change on the map: a review of approaches, benefits, and risks. Sustainability Science 2011, 6:177202.

71. Osthorst W, Mänz C. Types of cluster adaptation to climate change. Lessons from the port and logistics sector of Northwest Germany. Maritime Policy \& Management 2012, 39:227-248.

72. Mullett J, McEvoy D. Climate resilient seaports. In: Coasts and Ports 2011: Diverse and Developing: Proceedings of the 20th Australasian Coastal and Ocean Engineering Conference and the 13th Australasian Port and Harbour Conference: Engineers Australia; 2011.

73. Ng AKY, Chen S-L, Cahoon S, Brooks B, Yang Z. Climate change and the adaptation strategies of ports: The Australian experiences. Research in Transportation Business \& Management 2013, 8:186-194.

74. Stenek V, J.C. Amado R, Connell O, Palin S, Wright B, Pope J, Hunter J, McGregor W, Morgan B, Stanley R, et al. Climate Risk and Business: Ports. International Finance Corporation 2011.

75. Moser S, Ekstrom J. A framework to diagnose barriers to climate change adaptation. Proceedings of the National Academy of Sciences 2010, 107:22026.

76. Bierbaum R, Smith JB, Lee A, Blair M, Carter L, Chapin Iii FS, Fleming P, Ruffo S, Stults M, McNeeley S. A comprehensive review of climate adaptation in the United States: more than before, but less than needed. Mitigation and Adaptation Strategies for Global Change 2013, 18:361-406.

77. Preston BL, Westaway RM, Yuen EJ. Climate adaptation planning in practice: an evaluation of adaptation plans from three developed nations. Mitigation and Adaptation Strategies for Global Change 2010, 16:407-438.

78. Port of San Diego. The Climate Mitigation and Adaptation Plan of the Port of San Diego. 2013. Available at: http://www. portofsandiego.org/climate-mitigation-andadaptation-plan.html.

79. Becker A, Acciaro M, Asariotis R, Carera E, Cretegny L, Crist P, Esteban M, Mather A, 
Messner S, Naruse S, et al. A Note on Climate change adaptation for seaports: A challenge for global ports, a challenge for global society. Climatic Change 2013, 120:683-695.

80. EPA (United States Environmental Protection Agency). Planning for Climate Change Impacts at U.S. Ports. White Paper prepared by ICF International for the USEPA. 2008.

81. Dovers S. Normalizing adaptation. Global Environmental Change 2009, 19:4-6.

82. McEvoy D, Fünfgeld H, Bosomworth K. Resilience and climate change adaptation: the importance of framing. Planning Practice \& Research 2013, 28:280-293.

83. Holper P, Lucy S, Nolan M, Senese C, Hennessy K. Infrastructure and climate change risk assessment for Victoria. Consultancy Report to the Victorian Government prepared by CSIRO, Maunsell Australia, and Phillips Fox, Aspendale, Victoria, Australia 2007.

84. Port of Felistowe. Port of Felixstowe Climate Adaptation Report. 2015. Available at: https://www.gov.uk/government/uploads/system/uploads/attachment_data/file/53091 0/climate-adrep-port-felixstowe.pdf.

85. Port of Dover. Port of Dover Climate Adaptation Report. 2015. Available at: https://www.gov.uk/government/uploads/system/uploads/attachment_data/file/48808 7/climate-adrep-dover-port.pdf.

86. UN-Habitat. UN-Habitat Series of Vulnerability Assessments for Selected Cities in the Asia Pacific Region. Available at: http://unhabitat.org/series/climate-changevulnerability-assessments/.

87. Morris L, Sempier TT, D.L. Swann, R. Emmer, S.H. Sempier, and M. Schneider. Ports Resilience Index: A Port Managment Self-Assessment. 2016. Available at: http://www.gulfofmexicoalliance.org/documents/pits/ccr/ports_resilience_index.pdf.

88. Scott H, McEvoy D, Chhetri P, Basic F, Mullett J. Climate change adaptation guidelines for ports, Enhancing the resilience of seaports to a changing climate. Enhancing the resilience of seaports to a changing climate series 2013.

89. UKCIP (United Kingdom Climate Impacts Programme). AdOpt: Guiding Principles. 2011. Available at: http://www.ukcip.org.uk/wp-content/PDFs/ID_Adapt_options.pdf.

90. Moser S. Whether our levers are long enough and the fulcrum strong? Exploring the soft underbelly of adaptation decisions and actions. Adapting to climate change: Thresholds, values, governance 2009:313-334.

91. Adger WN, Agrawala S, Mirza MMQ Conde C, O’Brien K, Pulhin J, Pulwarty R, Smit B, Takahashi K. Assessment of adaptation practices, options, constraints and capacity. Climate change 2007:717-743.

92. Travis WR. Going to extremes: propositions on the social response to severe climate change. Climatic Change 2009, 98:1-19.

93. Kates RW, Travis WR, Wilbanks TJ. Transformational adaptation when incremental adaptations to climate change are insufficient. Proceedings of the National Academy of Sciences 2012, 109:7156-7161.

94. Becker A, Caldwell M. Stakeholder Perceptions of Seaport Resilience Strategies: A Case Study of Gulfport (Mississippi) and Providence (Rhode Island). Coastal Management 2015, 43:1-34.

95. Esteban M, Mikami T, Shibayama T, Takagi H, Jonkman SN, van Ledden M. Climate 
change adaptation in Tokyo Bay: The case for a storm surge barrier. Coastal Engineering Proceedings 2014, 1:35.

96. Cheong SM. Policy solutions in the US. Climatic Change 2011, 106:57-70.

97. Aerts J, Botzen Wj, Eamanuel K, Lin N, deMoel H, Michael-Kerjan E. Evaluating Flood Resilience Strategies for Coastal Megacities. Science 2014, 344:473-476.

98. MSPA (Mississippi State Port Authority). Gulfport Master Plan Update 2007 - Final Report. 2007.

99. Dircke PTM, Jongeling THG, Jansen PLM. An Overview and comparison of navigable storm surge barriers. In: Innovative Dam and Levee Design and Construction for Sustainable Water Management. New Orleans, LA; 2012.

100. McEvoy D, Mullett J. Enhancing the resilience of seaports to a changing climate: research synthesis and implications for policy and practice. Gold Coast, Australia: National Climate Change Adaptation Research Facility; 2013.

101. Moser SC, Boykoff MT. Successful adaptation to climate change: Linking science and policy in a rapidly changing world. London, England: Routledge; 2013.

102. T R, Ranger N. How do you adapt in an uncertain world? Lessons from the Thames Estuary 2100 project. World Resources Report 2011. Available at: http://www.worldresourcesreport.org/.

103. Knatz G. Foreward. In: Ng A, Becker A, Cahoon S, Chen S-L, Earl P, Yang Z, eds. Climate Change and Adaptation Planning for Ports. NY, NY: Routledge; 2016.

104. AGIC (Australian Green Infrastructure Council). AGIC Guidelines for Climate Change Adaptation. 2010.

105. Kintisch E. Roads, Ports, Rails Aren't Ready for Changing Climate, Says Report. Science 2008, 319:1744-1745.

106. Zhang H, Ng A. Climate change and adaptation planning for ports: a global study. Proceedings of the World Conference on Transport Research Conference (WCTR) 2016.

107. IFC (International Finance Corporation). How to Make Infrastructure Climate Resilience. EMCompass: Fresh Ideas about Business in Emerging Markets 2016, 14.

108. Duncan McIntosh R, Becker A. Seaport Climate Vulnerability Assessment at the Multi-port Scale: A Review of Approaches. In: Linkov I, Palma-Oliveira JM, eds. Resilience and Risk: Methods and Application in Environment, Cyber and Social Domains. Dordrecht: Springer Netherlands; 2017, 205-224.

109. Nicholls RJ, Hallegatte S, Corfee-Morlot J, Chateau J, Muir-Wood R, Hanson S, Herweijer C, Patmore N. Ranking Port Cities with High Exposure and Vulnerability to Climate Extremes. OECD 2008.

110. Esteban M, Thao ND, Takagi H, Shibayama T. Increase in Port Downtime and Damage in Vietnam Due To a Potential Increase in Tropical Cyclone Intensity. In: Climate Change and the Sustainable Use of Water Resources: Springer; 2012, 101-125.

111. Esteban M, Webersik C, Shibayama T. Methodology for the estimation of the increase in time loss due to future increase in tropical cyclone intensity in Japan. Climatic Change 2009, 102:555-578.

112. Chhetri P, Jayatilleke G, Gekara V, Manzoni A, Corbitt B. Simulating the impact of extreme weather events on port operations. 2015.

113. Becker A, Chase NTL, Fischer M, Schwegler B, Mosher K. A method to estimate climate-critical construction materials applied to seaport protection. Global Environmental Change 2016, 40:125-136. 
114. Becker A. Using boundary objects to stimulate transformational thinking: storm resilience for the Port of Providence, Rhode Island (USA). Sustainability Science 2016.

115. UK Department for Environment FRA, ,. Climate change adaptation reporting: second round reports. 2017. Available at:

https://www.gov.uk/government/collections/climate-change-adaptation-reportingsecond-round-reports - progress-reports:-harbour-authorities.

116. RCI (Rotterdam Climate Initative). Rotterdam Climate Change Adaptation Strategy. 2012.

117. Dircke P, Molenaar A. Smart climate change adaptation in Rotterdam, Delta City of the future. Water Practice and Technology 2010, 5:wpt2010083.

118. PMV (Port of Metro Vancouver). Port of Metro Vancouver. 2016. Available at: http://www.portmetrovancouver.com/.

119. Zhang H, Ng A. The regional efforts of Port Metro Vancouver in adapting to potential impacts posed by climate change. In: International Association of Maritime Economists (IAME). Hamburg, Germany; 20.

120. Fraser Basin Council. Flood and the Faser. 2016. Available at: http://www.fraserbasin.bc.ca/water_flood_fraser.html.

121. Church M, Currie M, Jakob M, Mitchell P. Professional practice guidelines-legislated flood assessments in a changing climate in BC. 2012.

122. Becker A, Hippe A, McLean E. Cost and Materials Required to Retrofit US Seaports in Response to Sea Level Rise: A Thought Exercise for Climate Response. Journal of Marine Science and Engineering 2017, 5:44.

123. UNCTAD (United Nations Conference on Trade and Development). Climate Change Impacts and Adaptation: A Challenge for Global Ports, Ad Hoc Expert Meeting (September 2011). In; 2012.

124. Moser SC, Boykoff MT. Climate change and adaptation success. In: Moser SC, Boykoff MT, eds. Successful adaptation to climate change: Linking science and policy in a rapidly changing world. Abingdon Routledge; 2013, 1-33.

125. Environment Agency. Thames Estuaty 2100: 5 Year Monitorin Review. 2016. Available at: https://www.gov.uk/government/uploads/system/uploads/attachment_data/file/55863 0/TE2100_5_Year_Review.pdf.

126. CoastAdapt. What is a pathways approach to adaptation? 2016. Available at: https://coastadapt.com.au/pathways-approach.

127. Berkhout F, Hertin J, Gann DM. Learning to adapt: organisational adaptation to climate change impacts. Climatic Change 2006, 78:135-156.

128. USGCRP (United States Global Change Research Program). National Climate Assessment. 2013. Available at: http://ncadac.globalchange.gov/. 


\section{Captions for Figures}

Graphical Abstract - Map showing 1100 ports (green) out of $~ 3700$ total (red) that have come within 50km of a tropical storm from 1960 - 2016. Storm tracks in orange. (data from World Port Index and https://www.ncdc.noaa.gov/ibtracs/). Increase in intensity of tropical storms is one of many climate drivers expected to affect seaports and supply chains.

Figure 1 - Map showing 1100 ports (green) our of $\sim 3700$ total (red) that have come within $50 \mathrm{~km}$ of a tropical storm from 1960 - 2016. Storm tracks in orange. (data from World Port Index and https://www.ncdc.noaa.gov/ibtracs/)

Figure 2 - Hybrid vulnerability/risk assessment process for ports ${ }^{81}$

Figure 3 - Jurisdiction map of Port of Vancouver, Canada ${ }^{104}$

Figure 4 - Conceptual model of a port and the main activities that can be affected by climate change. Diagram from the International Finance Corporation, World Bank, 2011 study of Terminal Maritimo Muelles el Bosque, Cartagena, Colombia ${ }^{68}$ 